\title{
The Effect of Periodic Maintenance on Pervious Concrete Pavements
}

\author{
Rodrigo Garozi da Silva ${ }^{1}$, Maria da Consolação Fonseca de Albuquerque ${ }^{1}$, \\ Marcelo Bortoletto ${ }^{1}$,Felipe de Almeida Spósito ${ }^{1}$, \\ Aparecido Carlos Gonçalves ${ }^{2}$, Marco Antonio de Morais Alcântara ${ }^{1}$
}

\footnotetext{
${ }^{1}$ Universidade Estadual Paulista, Department of civil engineering, Alameda Bahia, 550, CEP: 15.385-000, São Paulo, Ilha Solteira, Brazil.

${ }^{2}$ Universidade Estadual Paulista, Department of mechanical engineering, Avenida Brasil, 56, CEP: 15.385-000, São Paulo, Ilha Solteira, Brazil. e-mail: garozirodrigo@gmail.com, maria.albuquerque@unesp.br, marcelobortoletto05@gmail.com, felipsposito@gmail.com,marco.alcantara@unesp.br, aparecido.carlos@unesp.br
}

\begin{abstract}
Pervious concrete pavements are interesting from an environmental and social viewpoint. However, this type of pavement has as the main disadvantage of losing permeability over time by the clogging process. The aim of this work is to evaluate the periodic cleaning efficiency of using a blower, mainly during the first four months after paving. A pervious concrete sidewalk was constructed and cleaning was carried out, monthly in one half and weekly in the other half. Infiltration rate tests, following ASTM C1701, were performed weekly at eight spots arranged symmetrically on each half of the pavement. The results showed that using a blower for periodic cleaning was efficient. Both halves, with monthly and weekly cleaning, did not present significant statistical difference in their infiltration rates. In this sense, monthly maintenance is the most suitable due to less time and fuel are spent for cleaning, collaborating as an environmental-friendly alternative. This work showed that the performance of periodic maintenance can be useful, in order to maintain the efficiency of the pervious pavement over time.
\end{abstract}

Keywords: Pervious Concrete; Pavement; Infiltration Rate; Periodic Maintenance; Clogging.

\section{INTRODUCTION}

Surface waterproofing in urban areas usually occurs due to urbanization processes and, due to lack of planning, generate hydrological problems in certain regions. The main problems are associated with stormwater events that can cause floods and carry debris and pollutants. This promotes environmental and social damages and may even cause public health problems [1].

Pervious concrete pavements contribute to reduced or eliminated stormwater runoff in urbanized areas. It can be characterised as a rigid pavement solution or used as interlocking paving blocks that allows water infiltration through its porous structure. Thus, pervious concrete helps reduce or eliminate the pollutant load carried to rivers, increases groundwater recharge and also reduces temperatures in urban environments due to lower solar heat absorption [2-4]. It is basically composed of Portland cement, narrow grading coarse aggregates and in some cases fine aggregates. The cement paste should coat and bind the aggregate particles with satisfactory strength, maintaining a structure with a significant percentage of interconnected voids (about 15$35 \%$ ) [5, 6]. The binder-to-aggregate ratio is usually between 1:3 to $1: 7$ and some research can extrapolate these values [6]. To ensure satisfactory porosity, when fine aggregates are added, they usually represent 5$10 \%$ of the total aggregate amount, so that the small amount of mortar provides a porous granular skeleton balancing porosity and strength [7]. Admixtures can also be used in pervious concretes, mainly waterreducing or superplasticizers admixtures to increase fluidity and reduce the water-to-binder, collaborating to increase strength. Retarding admixtures help delay setting time of concrete and air-entraining admixtures can create millions of stabilized microscopic air bubbles that help the concrete to resist the effects of freezing and thawing [2]. Additions, mainly pozzolans (fly ash, silica fume, steel slag, etc.), can collaborate to increase strength and durability in freeze-thaw conditions, deicing chemicals, high-sulphate soils, and salt water [2, 8].

In general, the permeability rates of this type of concrete usually present great variability, with common values ranging from $0.2-0.54 \mathrm{~cm} / \mathrm{s}$ [3]. However, values ranging from zero to more than $2 \mathrm{~cm} / \mathrm{s}$ can be found 
in the literature $[6,9-13]$. Permeability of pervious concrete is strongly related to porosity. In the literature it is possible to find regression models that correlate permeability with porosity, in order to predict the hydraulic efficiency of pervious concretes [14]. The permeability generally tends to increase exponentially as the percentage of voids in pervious concrete increases, although the method to measure the infiltration rate can also influence the results and trends [15]. At the same time, compressive and tensile strengths tend to decrease exponentially $[11,12,16]$.

Over time, the permeability of pervious concrete tends to decrease due to clogging caused mainly by entrained debris and particles in its porous structure [3, 6, 17]. Care must be taken in the placement phase to avoid locations with a predisposition to carry debris. Some researchers have developed numerical models to predict permeability life of pervious concrete pavements [18, 19]. In addition, several investigations were carried out regarding the effect caused by sediment types and debris clogging the pores [6, 10, 17, 20, 21]. Sandoval et. al [18] proposed a model that allows to identify the clogging potential of a pervious concrete pavement, the final permeability and thus to predict with what concentration of sediment the pervious concrete loses its draining capacity. Such a model is useful to help predict the useful life of a pervious concrete pavement.

Coughlin et al. [17] reported that clay has a much higher clogging potential than sand. In addition, Kia et al. [10] concluded that the combination of sand and clay cycles in pervious concretes has a high clogging potential, even greater than sand and clay cycles applied separately and alternately. Kia et al. [10] still found that clogging begins with the formation of sand and clay flocculated layers that increase as the number of cycles increases. The clogging process generally occurs in three progressive phases. In the first there is quick clogging, then a slight increase in the permeability and, finally, progressive clogging. This process occurs due to the movement of particles in the internal void structure of the concrete until stabilization within a few minutes [20].

Some models of quantifying the permeability reduction by clogging were studied in the laboratory [19-21]. However, few surveys portray or describe service life models for pervious pavements with respect to clogging, since this depends on many external factors specific to each situation. Sandoval et. al [19] propose a maintenance periodicity based on the concentration of sediments by applying a soil erosion mechanics analysis. In other words, by performing a correlation between the sediment concentration (applying Universal Soil Loss Equation - USLE) with time, it is possible to estimate cleaning periods for different types of sediment.

Saaly et al. [22] studied the permeability rate of pervious concrete slabs by simulating continuous and intermittent raining conditions without any type of maintenance over four months. The slabs were exposed to the external environment. According to their study, the permeability decreased dramatically over the four months from more than $12 \mathrm{~cm} / \mathrm{s}$ initially, to less than $2 \mathrm{~cm} / \mathrm{s}$ in the last few weeks. According to the model they developed, this reduction occurred exponentially. Winston et al. [23] also noticed a permeability reduction over the years in pavements built in northern Sweden.

Kayhanian et al. [9] studied 20 pervious concrete pavements in parking lots in different regions of California (USA) and found permeability rates ranging from zero to $1.986 \mathrm{~cm} / \mathrm{s}$. These permeability rates were measured on pavements with different ages and age seemed to be the main factor for reduced permeability.

There are several methods to recover permeability in clogged pavements, the main ones being: street sweeping, vacuum cleaning, high-pressure washing and milling. Winston et al. [23] studied all these treatments in different porous asphalt pavements and realized that all the methods brought improvements to the permeability rates. The high-pressure wash showed significant permeability recovery and appeared to be more efficient than street sweeping and vacuum cleaning. However, milling was the technique that showed the greatest efficiency in permeability recovery, although it is the most expensive, by the removal and reinstallation of part of the porous asphalt's surface layer. Delatte et al. [16] found that high-pressure washing on a severely clogged pavement improved the infiltration capacity by about $35 \%$. The most suitable cleaning method can still be related to the type of sediment deposited on the pervious pavement. Regenerative air cleaning can efficiently remove sand sediments, due to facilitate the expulsion of particles deposited in internal pores. For fine sediments such as clay, high-pressure washing can be more efficient, due to the breaking of the Van der Waals forces between the sediment particles, promoting the removal of particles [19]. Table 1 summarises the main types of maintenance procedures studied for pervious pavements and the main results observed. 
Table 1: Summary of the main types of maintenance procedures studied in literature

\begin{tabular}{|c|c|c|}
\hline AUTHOR & TYPE OF MAINTENANCE & MAIN RESULTS \\
\hline $\begin{array}{l}\text { Winston et } \\
\text { al. [23] }\end{array}$ & $\begin{array}{l}\text { Street sweeping, vacuum cleaning, high- } \\
\text { pressure washing and milling }\end{array}$ & $\begin{array}{l}\text { All the methods brought improvements to the permeability } \\
\text { rates. The high-pressure wash showed significant permea- } \\
\text { bility recovery and appeared to be more efficient than street } \\
\text { sweeping and vacuum cleaning. However, milling was the } \\
\text { technique that showed the greatest efficiency in permeabil- } \\
\text { ity recovery, although it is the most expensive }\end{array}$ \\
\hline $\begin{array}{c}\text { Delatte et al. } \\
{[16]}\end{array}$ & High-pressure washing & $\begin{array}{c}\text { An improvement of about } 35 \% \text { in infiltration capacity was } \\
\text { achieved on a severely clogged pavement }\end{array}$ \\
\hline $\begin{array}{l}\text { Sandoval et } \\
\text { al. [19] }\end{array}$ & $\begin{array}{c}\text { Surface cleaning (with a broom), air cleaning } \\
\text { (with a compressor) and high-pressure wash- } \\
\text { ing }\end{array}$ & $\begin{array}{c}\text { Regenerative air cleaning can efficiently remove sand sed- } \\
\text { iments, while high-pressure washing can be more efficient } \\
\text { for fine sediments such as clay. Surface cleaning with a } \\
\text { broom did not shows any permeability improvement in any } \\
\text { case }\end{array}$ \\
\hline $\begin{array}{l}\text { Henderson } \\
\text { and Tighe } \\
\text { [24] }\end{array}$ & $\begin{array}{c}\text { Sweeping with a stiff household broom to } \\
\text { agitate the debris in the voids, and after rins- } \\
\text { ing the surface with a garden hose }\end{array}$ & It was effective to improve the permeability \\
\hline $\begin{array}{l}\text { Vancura et } \\
\text { al. [25] }\end{array}$ & \begin{tabular}{|c|} 
Regenerative air street sweeper, vacuum truck \\
with a flexible $200 \mathrm{~mm}$ hose and a vacuum \\
street sweeper (common municipal utility \\
vehicles for cleaning pavements)
\end{tabular} & $\begin{array}{l}\text { The three cleaning methods were equally able to remove } \\
\text { clogging materials that were located within } 3.18 \mathrm{~mm} \text { of the } \\
\text { surface }\end{array}$ \\
\hline $\begin{array}{l}\text { Hein et al. } \\
\quad[26]\end{array}$ & $\begin{array}{l}\text { Pressure washing, vacuuming and power } \\
\text { blowing, to restoring pervious concrete per- } \\
\text { meability }\end{array}$ & $\begin{array}{l}\text { Vacuuming and pressure washing are equally effective to } \\
\text { improve the infiltration rate of the pavement clogged. Pow- } \\
\text { er blowing provides no improvement on infiltration rate, if } \\
\text { it follows pressure washing }\end{array}$ \\
\hline
\end{tabular}

Usually, effective maintenance techniques are applied to pervious pavements when their infiltration capacity becomes partially or totally compromised but performing preventive maintenance is not common. Periodic sweeping (daily, weekly or monthly) is carried out in some pervious pavements but without studies in deep detail about the permeability rate behaviour over time [23].

However, some authors have asserted about maintenance types and regimens. Mechanical sweeping is not a recommended method, because it pushes particles deeper into the pavement rather than removing it [6]. However, Henderson and Tighe [24] found that sweeping with a stiff household broom to agitate the debris in the voids, and after rinsing the surface with a garden hose is effective to improve the permeability. Another method that can be used is the regenerative air street sweeper to removing clogging material on surface. Vancura et al. [25] asserted the regenerative air street sweeper were able to remove clogging materials that were located within $3.18 \mathrm{~mm}$ of the surface as well as a vacuum truck with a flexible $200 \mathrm{~mm}$ hose and a vacuum street sweeper. They evaluate the efficiency of the three mentioned methods because are common municipal utility vehicles for cleaning pavements. Three different locations, with different characteristics of the pervious concrete were chosen by the authors for each test. Moreover, the authors found that the rate at which clogging material is consolidated into the voids of pervious concrete determines the maintenance frequency required to remove clogging material of voids. This rate depends on the amount of particulate matter in the stormwater runoff directed to the pervious pavement surface, the location of the pervious concrete in its drainage area, the variation in the rate of organic material from the surrounding vegetation and modifications made to surrounding areas that may influence the amount debris in the pavement (soil erosion). For instance, in the locations studied by the authors, the pervious concrete with more clogging material in the structure voids required maintenance every 3-4 weeks to maintain permeability, because after a month of the maintenance, the pavement was again totally waterproof. At the location where the maintenance was performed by the regenerative air street sweeper, it was suggested that maintenance every three months is adequate to 
maintain the functional permeability, due the relative lack of clogging material within the voids.

According to Kia et al. [6], maintenance has to be regular or clogging will affect the pavement so that maintenance will no longer be effective. Moreover, according to the authors, even if the maintenance was carried out regularly, the infiltration rates are not fully recovered and the performance of the pervious concrete will drop over time to unacceptable levels due to the cumulative effects of material clogging.

Hein et al. [26] studied the effectiveness of pressure washing, vacuuming and power blowing, to restoring pervious concrete permeability. According to the authors, vacuuming and pressure washing are equally effective to improve the infiltration rate of the pavement clogged. However, power blowing provides no improvement on infiltration rate, if it follows pressure washing. There are no studies about the use of blowers to preventive maintenance in periodic regime of cleaning in the same place.

This work aims to perform an analysis of pervious concrete pavement behaviour in terms of its infiltration rate over time with periodic cleaning. For this, maintenance was performed through periodic weekly and monthly cleaning (usual street cleaning regime at the study site) with a blower during the first four months of service life to analyse the efficiency of both regimens in the same place. The maintenance program was started at the earliest ages and the influence of age was analysed using a statistical test to prove the validity of the graphical analyses.

\section{EXPERIMENTAL PROGRAM}

A $1.00 \times 10.00 \mathrm{~m}$ pervious concrete sidewalk was constructed for the infiltration rate analyses. The sidewalk was initially designed to promote infiltration of all flush and totally mitigate the precipitation. The design aimed to meet the maximum rainfall for a 100-year return time [27], considering the local soil infiltration and the water storage capacity in the pavement structure voids. These are the main factors to consider when designing pervious concrete so that stored water does not overflow the structure and form sheets of water. To promote infiltration of water into the reservoir, the concrete must have an infiltration rate of at least 0.0051 $\mathrm{cm} / \mathrm{s}$, which is the maximum flow considered in the design.

The pervious pavement was built in the College of Engineering of Ilha Solteira - University of São Paulo State (Ilha Solteira, State of São Paulo, Brazil). The local rainy tropical climate causes high rainfall in the hottest months, with average maximum daily temperatures above $32^{\circ} \mathrm{C}$, and in the cooler months, dry weather is common, with average maximum daily temperatures up to $28^{\circ} \mathrm{C}$ [28].

The local soil where the pavement was constructed is a dark red Latosol with a typically sandy texture, a highly porous structure and no active clay minerals [29]. The average hydraulic conductivity values are $18.72 \mathrm{~mm} / \mathrm{h}$ under natural conditions (J. A. Lollo, personal communication, July 2018 [30]).

The construction site of the pavement is flat, without runoff or drainage from surrounding areas on rainy days. The sidewalk was built $2 \mathrm{~cm}$ above ground level to avoid material flow onto pavement surfaces. Although there were many trees all over the university campus, there were no trees close to the pavement; that is, at the chosen site, the pavement had a low incidence of organic debris. Thus, the main source of clogging is the leaves of trees and dust, both carried by the wind.

The pervious pavement was composed of a sub-base layer with basaltic coarse aggregates directly placed over local soil in the natural condition (only regularized), to be subsequently paved with pervious concrete.

The flowchart (Figure 1) summarises the experimental program and presents all the steps that will be explained later. 


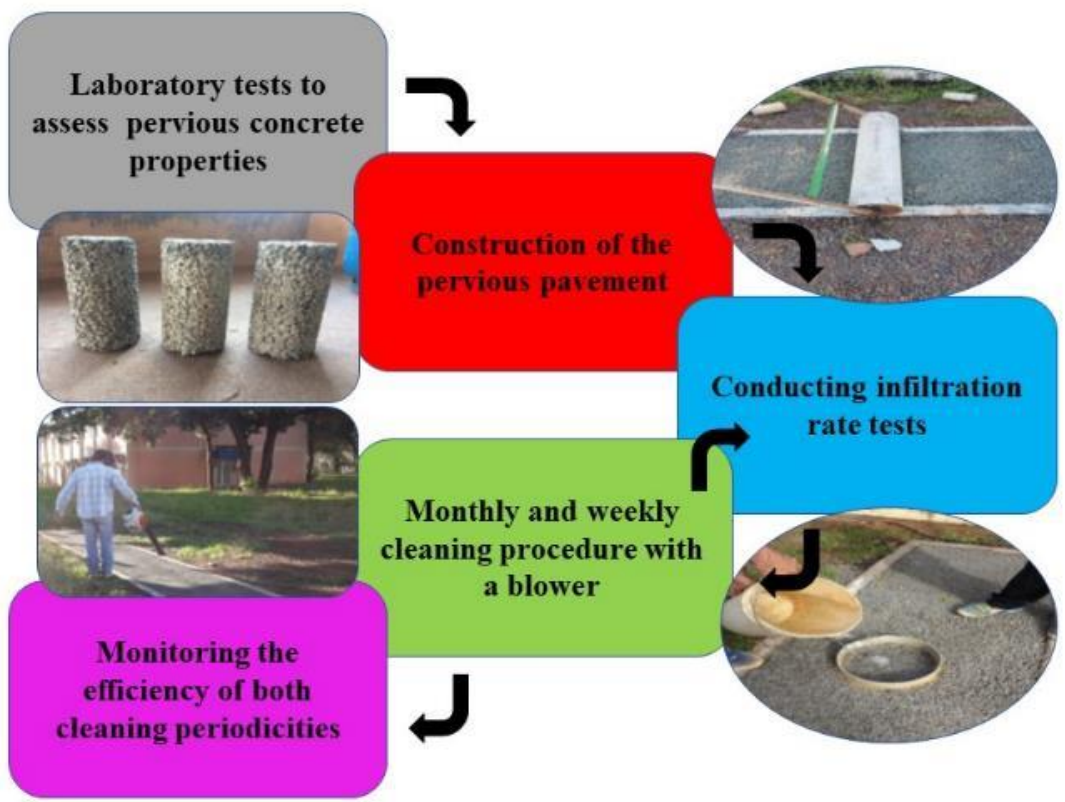

Figure 1: Flowchart of experimental program

\subsection{Material}

For the pervious concrete mixture, only crushed basaltic stone coarse aggregates were used, provided by Mineração Grandes Lagos in Itapura, State of São Paulo. The gradation range varied from 4.75 to $12.5 \mathrm{~mm}$, as specified in NBR 7211 [31]. This aggregate gradation is close to that observed in the literature [3, 6, 11, 22]. For the sub-base layer, the same coarse crushed aggregates were used, but with a larger 9.5 to $25.0 \mathrm{~mm}$ gradation, according to NBR 7211 [31]. Figure 2 shows the gradation distribution of the aggregates used.

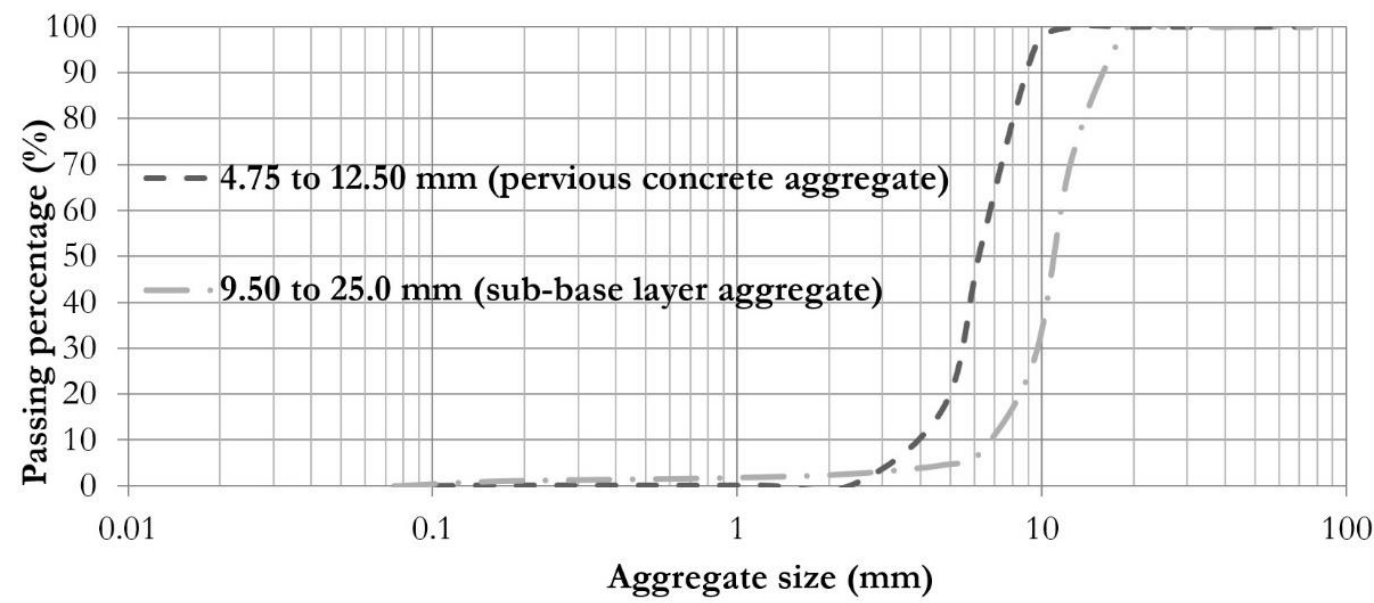

Figure 2: Gradation curves of coarse aggregate

A Brazilian Portland cement type CP II F - 40, containing 11-25\% of carbonaceous material (specified on NBR 16697 [32]), supplied by Votorantim Cimentos was used. More details about the cement can be found in the technical report provided by the company [33]. To adjust the workability of the fresh mixture, a polycarboxylate based superplasticizer (TEC-FLOW 7000), supplied by GCP Applied Technologies, was also used.

Before pavement construction, laboratory tests were conducted to characterise the pervious concrete's mechanical properties. After preliminary tests, 1:5 (cement:aggregate) mix was chosen, with 0.29 water-tobinder and a polycarboxylate superplasticizer ( $0.5 \%$ of binder content). This mix design is in accordance with parameters indicated by the literature $[6,34]$. Compressive strength, splitting tensile strength and flexural strength tests were performed for the chosen mix. For the compressive strength and splitting tensile 
strength tests, eight $\varnothing 10 \times 20 \mathrm{~cm}$ cylindrical concrete specimens were cast and six $15 \times 15 \times 50 \mathrm{~cm}$ beam specimens were produced for flexural strength tests. The cylindrical pervious concrete specimens were moulded in three layers with 15 blows of steel rod per layer, followed by 10 seconds on vibrating table. The beam specimens were produced in two layers with 25 blows of steel rod per layer, followed by 10 seconds on vibrating table. These procedures were carried out according to Batezini [35]. These were cured in a concrete curing room at $95 \%$ relative humidity for 28 days. The tests were performed following the recommendations of ASTM C39 [36], ASTM C496 [37] and ASTM C78 [38] for compressive strength test, splitting tensile strength test and flexural strength test, respectively. The physical properties were also investigated by determining the density (unit weight) and void content according to the method prescribed by ASTM C1688 [39] and water absorption, as described in ASTM C642 [40]. The infiltration rate was measured in the laboratory as follows. Cylindrical specimens were wrapped with a shrink wrap plastic film along its length, leaving a 50 $\mathrm{mm}$ lip above the top to maintain a head water. After a pre-wetting to allow water to flow through the specimen, 2 litres of water were then poured on its top surface, keeping a constant water head of about $2 \mathrm{~cm}$. The infiltration rate is given by the volume poured divided by the cross-sectional area times the time spent to pour the water. This test is described in detail by ISO 17785-1 [41]. Figure 3 presents the infiltration rate test setup.

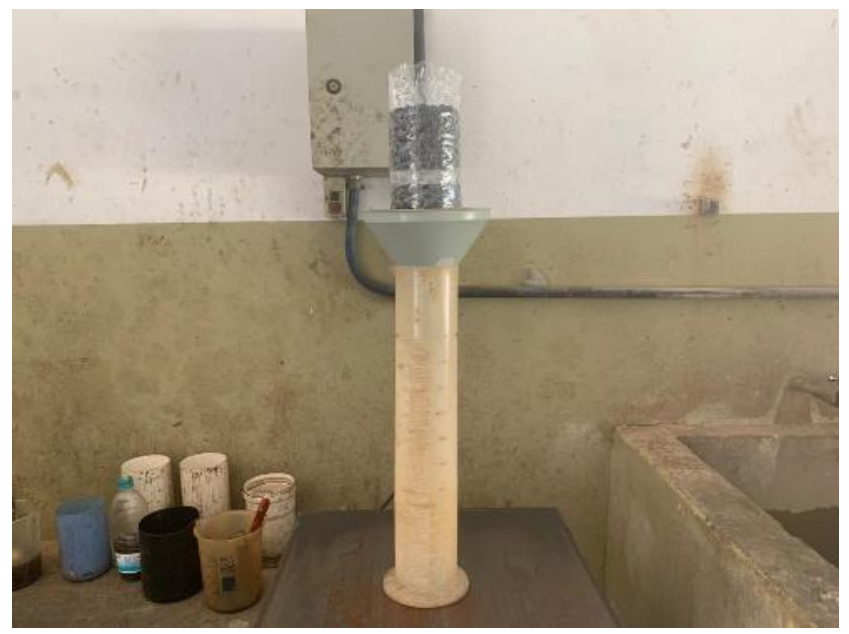

Figure 3: ISO 17785-1 infiltration rate test setup

After characterization in the laboratory, a slab test $(1.00 \times 1.00 \mathrm{~m})$ of the design pavement with the same thickness was placed with the pervious concrete characterised to guarantee that the chosen mixture was not blocked by paste drain down in the construction phase, which would make pavement water infiltration inefficient. The whole procedure of concrete slab placement and consolidation was repeated later in the construction of the sidewalk. The pavement construction was monitored for sealing.

\subsection{Construction of the pervious pavement}

The first stage was delimiting the area and regularizing the soil. The site was excavated and the subgrade surface was only planed without receiving any compaction. Subsequently, a $10 \mathrm{~cm}$ thick perimeter curb was built around the sidewalk contour, delimiting the area for later placement. The sub-base layer of crushed aggregates was then placed, smoothed and moistened. Wetting the sub-base just prior to placement is necessary to prevent it from absorbing water from the concrete mixture [3]. The concrete was mixed and placed by a concrete mixer truck, provided by the Brambilla company. The top layer was spread and consolidated with a steel roll passed 3 times in a single layer, which provided the finish. The consolidation roller is approximately $61 \mathrm{~kg}$ with $1 \mathrm{~m}$ length. This roll is similar to recommended for consolidation and regularization by ACI 522R [42], with a proportional reduction in length in order to consolidate the pavement efficiently, maintaining the same weight/length specified in the respective ACI. This compaction process was considered adequate because the initial infiltration rates of the pavement (central region of the sidewalk was $1.28 \mathrm{~cm} / \mathrm{s}$ to $1.59 \mathrm{~cm} / \mathrm{s})$ are similar to the infiltration rate measured in the laboratory tests $(1.32 \mathrm{~cm} / \mathrm{s})$. Figure 4 shows a schematic cross-section of the pavement. 


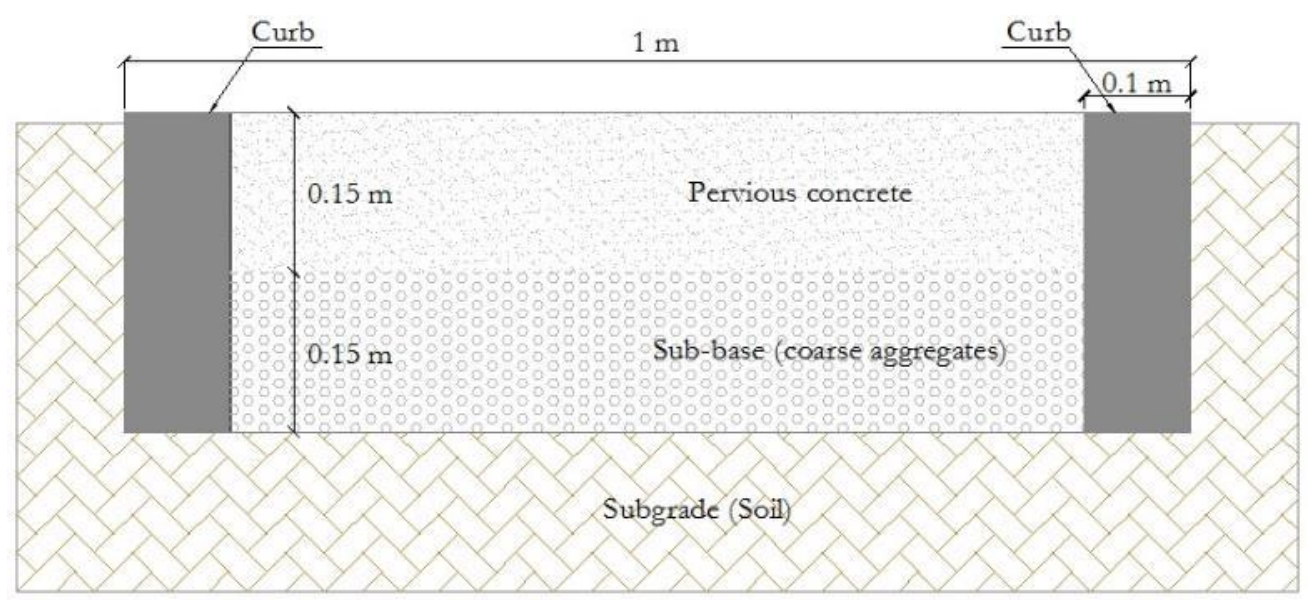

Figure 4: Schematic cross-section of the sidewalk

The literature recommends that curing be performed for at least seven days with plastic sheeting immediately after placement and compacting [3]. In this study, curing was carried out over a 14-day period by covering with plastic sheeting; water was sprayed on the pervious concrete surface every day to maintain moisture. Figure 5 shows the stages of pavement construction.

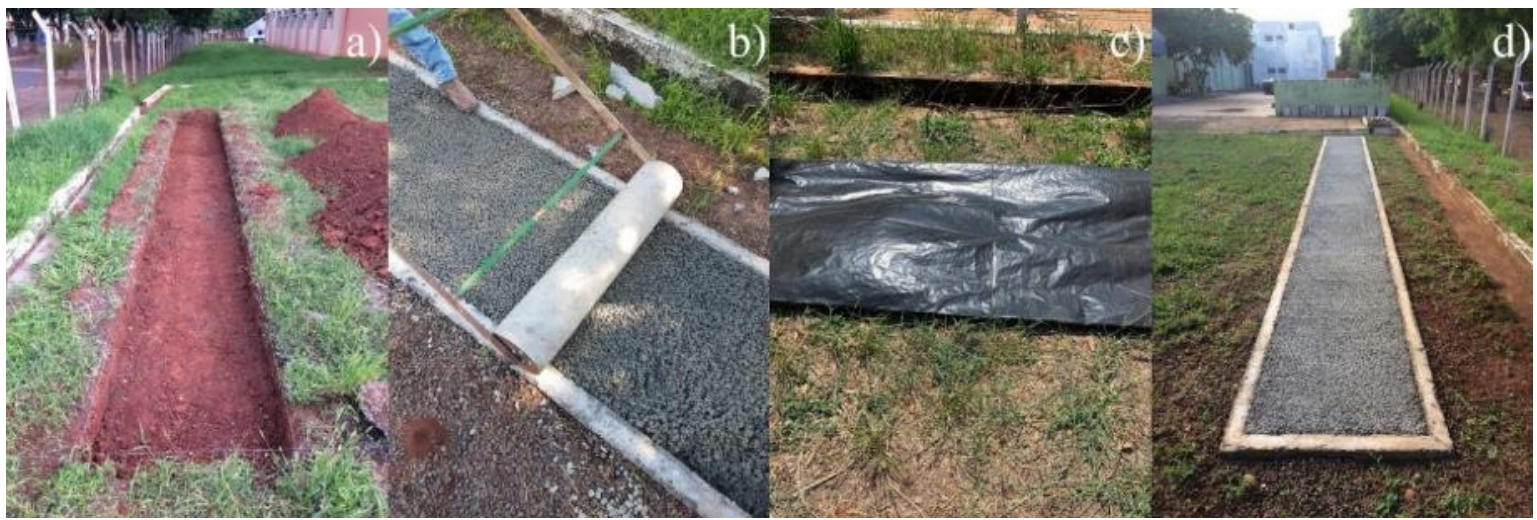

Figure 5: Stages of pavement construction: (a) Excavation; (b) Placement, consolidation and finishing; (c) Curing procedure; (d) Finished pavement

\subsection{Infiltration rate tests}

Infiltration rate tests were performed according to ASTM C1701 [43]. For this test, a $30 \mathrm{~cm}$ diameter cylindrical ring was placed on the pavement surface and sealed along its bottom edge so that when water was poured into it, it kept a constant head between 1 and $1.5 \mathrm{~cm}$ until all the water was poured (Figure 6). The sealing used bentonite clay instead of the plumber's putty specified in the standard due to the superior performance of clay under the high ambient temperatures conditions common in the study region $\left(>25^{\circ} \mathrm{C}\right)$. Drake and Bradford [44] used a similar change in sealing material under similar climatic conditions. As advised by ASTM C1701 [43], $18 \mathrm{~kg}$ of water were used to perform the test, after a pre-wetting. The result for each spot was the average of two tests conducted in sequence. 


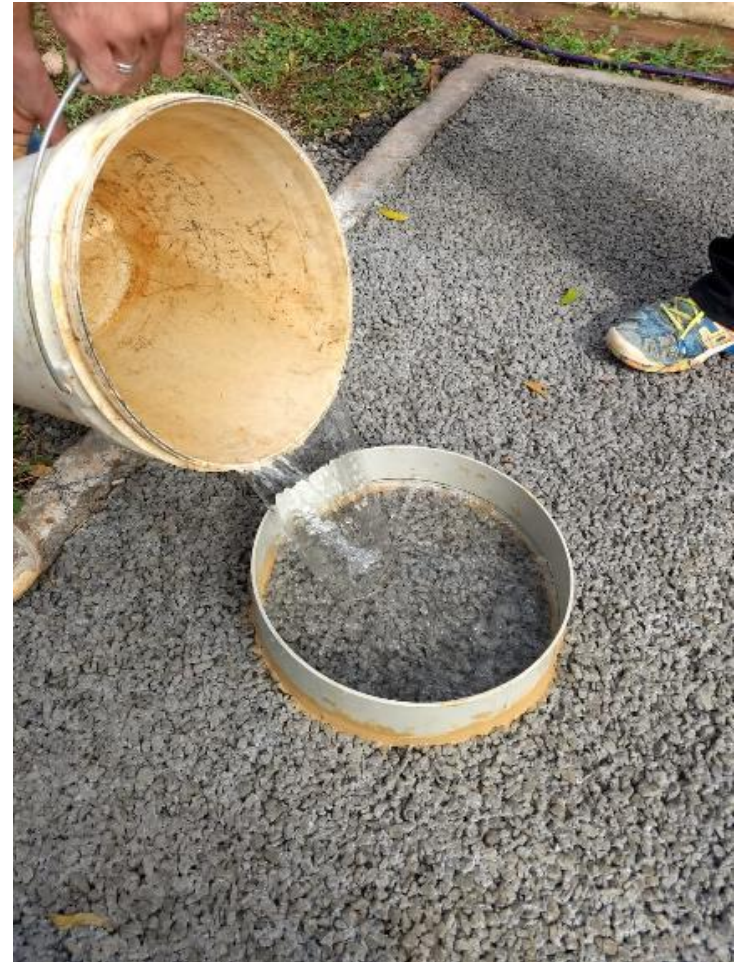

Figure 6: ASTM C1701 infiltration rate test

The blower can be used to clean gardens, grounds, agricultural machinery, industrial areas, and large public areas and for stadium and highway maintenance, as indicated by the supplier. Cleaning is carried out by blowing the surfaces. As pervious concrete is normally used in large public areas and private parking lots, the efficiency of periodic cleaning with this equipment was studied in this work (Figure 7). The equipment used in this work was a Still gas blower BG 86, with engine power of $0.8 \mathrm{~kW}$ (1.1 hp), maximum air flow rate of $810 \mathrm{~m}^{3} / \mathrm{h}$, and air velocity of $85 \mathrm{~m} / \mathrm{s}$ (with fan nozzle). The blown was performed with the nozzle inclined $45^{\circ}$ and $10 \mathrm{~cm}$ above the surface. It was blown from the edges to the centre in each half of the pavement.

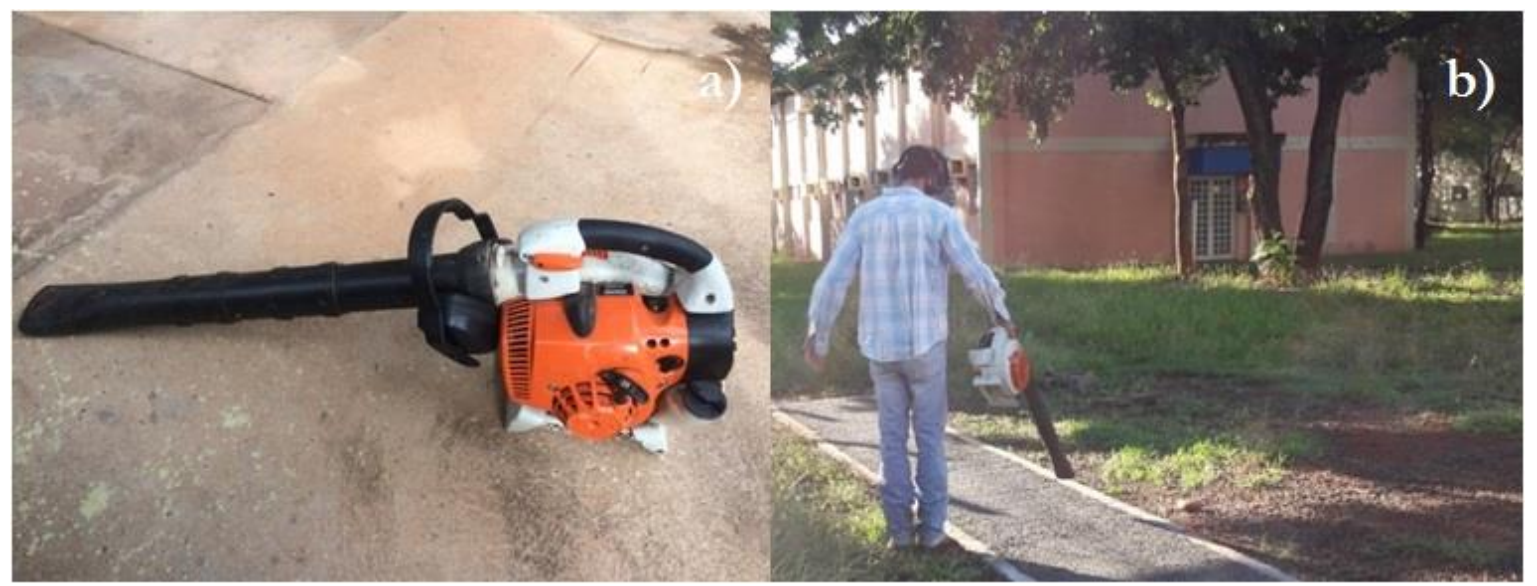

Figure 7: (a) Blower equipment; (b) Pavement cleaning

Soon after removing the plastic sheeting, field infiltration rate tests were started. In total, eight equally spaced spots were selected on the pavement surface so that it was possible to know the infiltration rate of the entire area of the pavement. In half of the sidewalk, maintenance with a blower was performed every 28 days, while in the other half, the same cleaning procedure was performed weekly, every 7 days. The spots for field infiltration rate measurement in the half in which maintenance was performed monthly were numbered 1-4 while the spots for infiltration rate measurement in the half in which weekly maintenance was performed 
were numbered 5-8. The spots were arranged symmetrically in the two halves, with some spots placed in the corners, near the ends of the curb, while others were placed more to the centre, away from the curbs. These locations were selected to observe any variability due to the distance from the edge and obtain a general average for the pavement, considering the regions of edges and centres. Figure 8 shows the locations of the test spots on the constructed sidewalk.

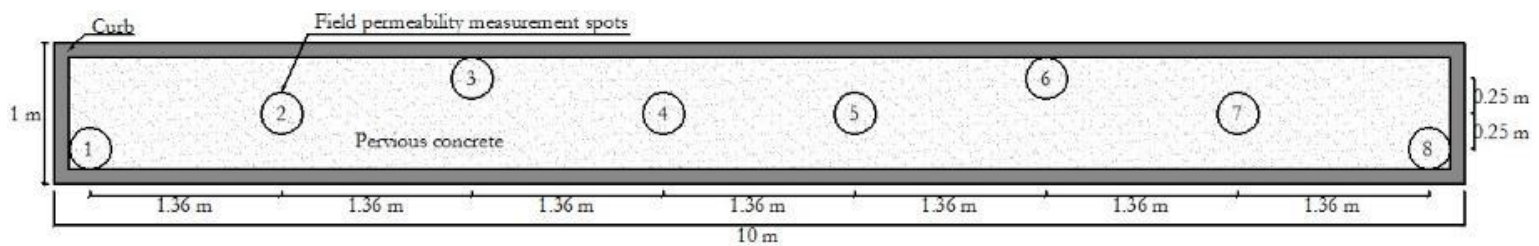

Figure 8: Top view of the pavement and locations of the infiltration rate test spots

The field infiltration rate tests in the eight spots began shortly after removing the plastic sheeting, on 19 December 2018 and, thereafter, were carried out weekly in all spots, always on Wednesdays, until 3 April 2019, totalling approximately four months. In spots 5-8, the tests were performed immediately after the weekly cleaning. At spots $1-4$, as cleaning was performed every four weeks, the weekly infiltration rate tests were performed after cleaning only on the cleaning week. In the other weeks, the test was done without any type of cleaning, except if there was some coarse debris that would interfere with the test, it was removed. The field infiltration rate tests were performed always in the same spots every week. Table 2 summarises the infiltration rate tests performed and the cleaning periodicity.

Table 2: Summary of infiltration test and cleaning schedule

\begin{tabular}{c|c|c|c}
\hline SPOTS & $\begin{array}{c}\text { CLEANING } \\
\text { PERIODICITY }\end{array}$ & $\begin{array}{c}\text { INFILTRATION RATE } \\
\text { TESTS PERIODICITY }\end{array}$ & CONDITIONS TO INFILTRATION RATE TESTS \\
\hline $\begin{array}{c}1 \text { to } 4 \\
\text { (monthly cleaning) }\end{array}$ & 28 days & 7 days & $\begin{array}{c}\text { The test was done weekly without any type of cleaning, } \\
\text { except if there was some coarse debris that would interfere } \\
\text { with the test, it was removed. Only every four weeks (28 } \\
\text { days), the weekly infiltration rate tests were performed after } \\
\text { cleaning }\end{array}$ \\
\hline $\begin{array}{c}5 \text { to } 8 \\
\text { (weekly cleaning) }\end{array}$ & 7 days & 7 days & \begin{tabular}{c} 
Immediately after the weekly cleaning \\
\hline
\end{tabular}
\end{tabular}

\section{RESULTS AND DISCUSSIONS}

\subsection{Pervious concrete properties on preliminary laboratory investigation}

Table 3 shows the average values and respective standard deviations for the concrete characterised in laboratory.

Table 3: Main characteristics of the pervious concrete

\begin{tabular}{|c|c|c|c|c|c|c|c|}
\hline $\begin{array}{c}\text { VOID } \\
\text { CONTENT } \\
(\%) \\
\text { ASTM } \\
\text { C1688 } \\
\end{array}$ & $\begin{array}{c}\text { CEMENT } \\
\text { CONTENT } \\
\left(\mathrm{KG} / \mathrm{M}^{3}\right)\end{array}$ & $\begin{array}{c}\text { DENSITY } \\
\left(\mathrm{KG} / \mathrm{M}^{3}\right) \\
\text { ASTM } \\
\text { C1688 }\end{array}$ & \begin{tabular}{|c|} 
WATER \\
ABSORP- \\
TION (\%) \\
ASTM \\
C642 \\
\end{tabular} & $\begin{array}{c}\text { COMPRESSIVE } \\
\text { STRENGTH AT } \\
\text { 28-DAY (MPA) } \\
\text { ASTM C39 }\end{array}$ & $\begin{array}{c}\text { SPLITTING } \\
\text { TENSILE } \\
\text { STRENGTH AT } \\
\text { 28-DAY (MPA) } \\
\text { ASTM C496 }\end{array}$ & $\begin{array}{c}\text { FLEXURAL } \\
\text { STRENGTH AT } \\
\text { 28-DAY (MPA) } \\
\text { ASTM C78 }\end{array}$ & $\begin{array}{c}\text { INFILTRATION } \\
\text { RATE (CM/S) } \\
\text { ISO 17785-1 }\end{array}$ \\
\hline 27 & 310 & 1957 & 5.25 & 11.71 & 1.51 & 3.33 & 1.32 \\
\hline
\end{tabular}




\begin{tabular}{l|l|l|l|l|l|l|l}
\hline & & $( \pm 23.62)$ & $( \pm 0.10)$ & $( \pm 3.07)$ & $( \pm 0.42)$ & $( \pm 0.05)$ & $( \pm 0.14)$ \\
\hline
\end{tabular}

According to the NBR 16416 [45] the minimum permeability required for a pervious concrete pavement is $0.1 \mathrm{~cm} / \mathrm{s}$, and the minimum flexural strength is $1 \mathrm{MPa}$ for pedestrian traffic and $2 \mathrm{MPa}$ for low vehicle traffic. The results observed in this laboratory investigation, were higher than the values required by the NBR 16416 [45], reaching an average infiltration rate of $1.32 \mathrm{~cm} / \mathrm{s}$ and flexural strength of $3.33 \mathrm{MPa}$. Void content, density, compressive strength and splitting tensile strength were close to values indicated by the literature for similar mix proportions concretes [6, 34].

\subsection{Initial infiltration rate}

The infiltration rate of the pavement soon after removing the plastic sheeting was divergent among the eight spots (Figure 9). However, similar behaviour was observed in spots measured in the same symmetrical position. For example, the highest infiltration rates were observed at spots 3 and 6 , both located symmetrically close to the curb, reaching infiltration rates of $1.86 \mathrm{~cm} / \mathrm{s}$ and $1.96 \mathrm{~cm} / \mathrm{s}$, respectively. On the other hand, spots 2, 4, 5 and 7, all central, had initial infiltration rates that also varied with close values, from $1.28 \mathrm{~cm} / \mathrm{s}$ to 1.59 $\mathrm{cm} / \mathrm{s}$. Only the corner spots, 1 and 8 , did not present similarities, exhibiting infiltration rates of $1.35 \mathrm{~cm} / \mathrm{s}$ and $1.71 \mathrm{~cm} / \mathrm{s}$, respectively. The mean value of all eight spots was $1.57 \mathrm{~cm} / \mathrm{s}$. These values are in agreement with the values found by Kayhanian et al. [9]. All infiltration rates are above the minimum value $(0.10 \mathrm{~cm} / \mathrm{s}) \mathrm{re}-$ quested by NBR 16416 [45].

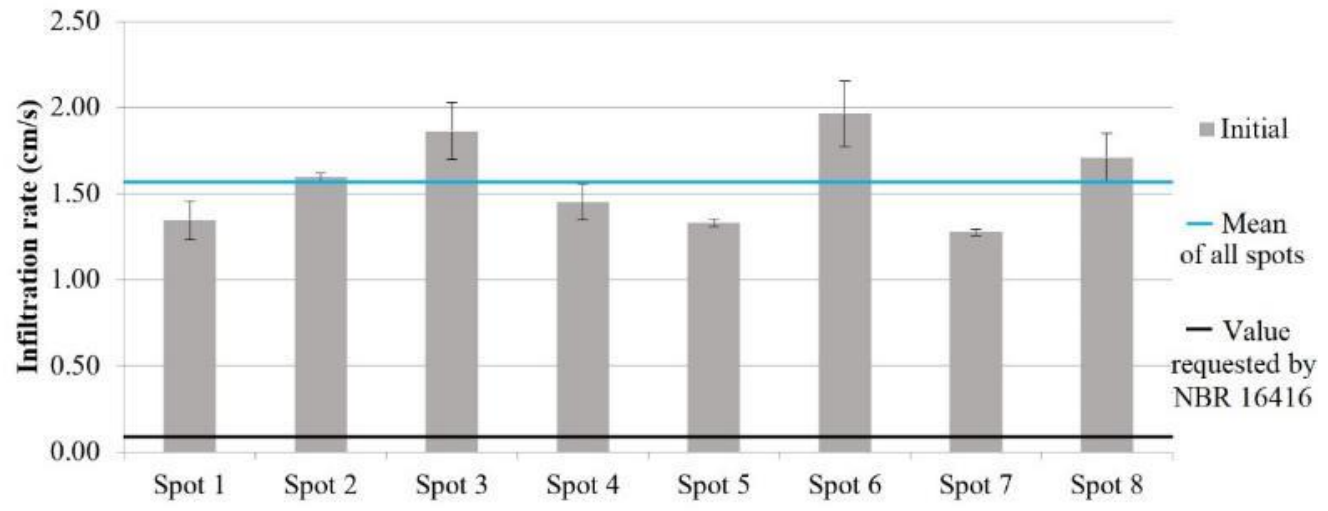

Figure 9: Initial infiltration rate of the pavement

Except for spot 1, all three other spots close to the curb, 3, 6 and 8, presented initial infiltration rates higher than the centred spots. The probable explanation for this phenomenon is the unequal compaction that can occur in different regions of the pavement. Figure 10 shows that the concrete closer the curbs was more porous and less compact than in the centres. This lower compactness increases the flow rate of water and provides greater percolation, thus making the pavement slightly more permeable near the curbs. Consequently, their strength should fall. From these observations, to get around this situation, it might be useful to use smaller roller so that it is passed more often close to the curb, where more attention is needed. 


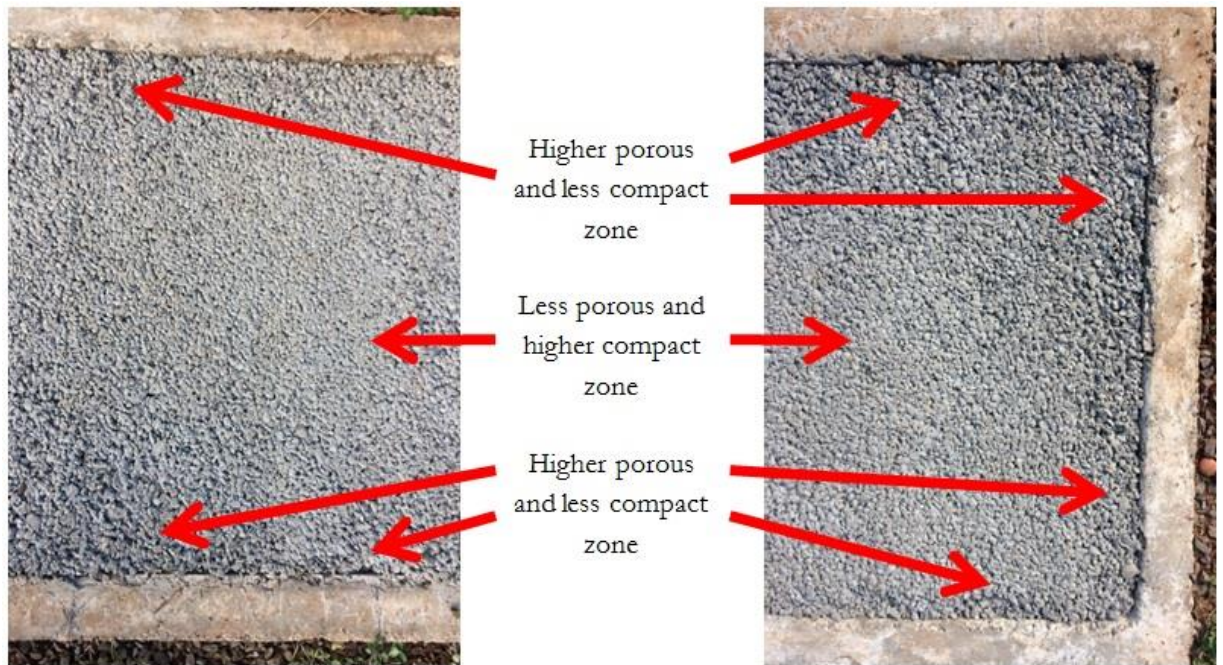

Figure 10: Pavement surface

\subsection{Comparison between different spots}

To better understand the behaviour between corresponding spots of the weekly and monthly cleaning regions, a comparison of the infiltration rates over time was carried out (Figures 11-14). The daily rainfall events in the region of the study throughout the analysis period were also inserted in the comparison. Rainfall data were obtained through the Climate Channel of UNESP - Ilha Solteira, which provides meteorological variables obtained by automatic weather stations in some cities of the Northwest of São Paulo state [46]. The data used were from the station located in the city of Ilha Solteira, which is just over a kilometre from the site of the sidewalk. It is important to note that infiltration rate measurement was always performed without rainfall. As the tests were always performed in the morning, it did not rain before or during the test; that is, the rains occurred in the afternoon or evening when it rained on test days.

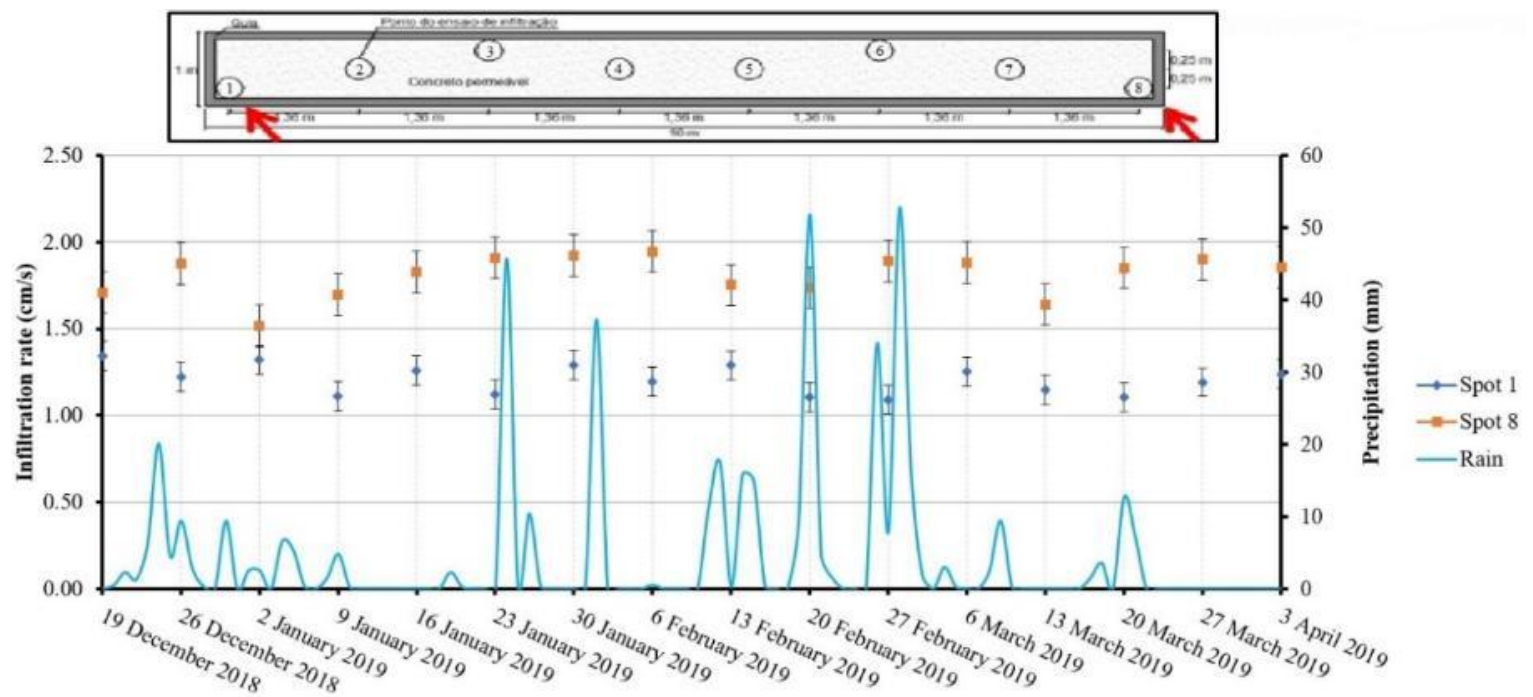

Figure 11: Comparison between the infiltration rates of spots 1 and 8 over time 


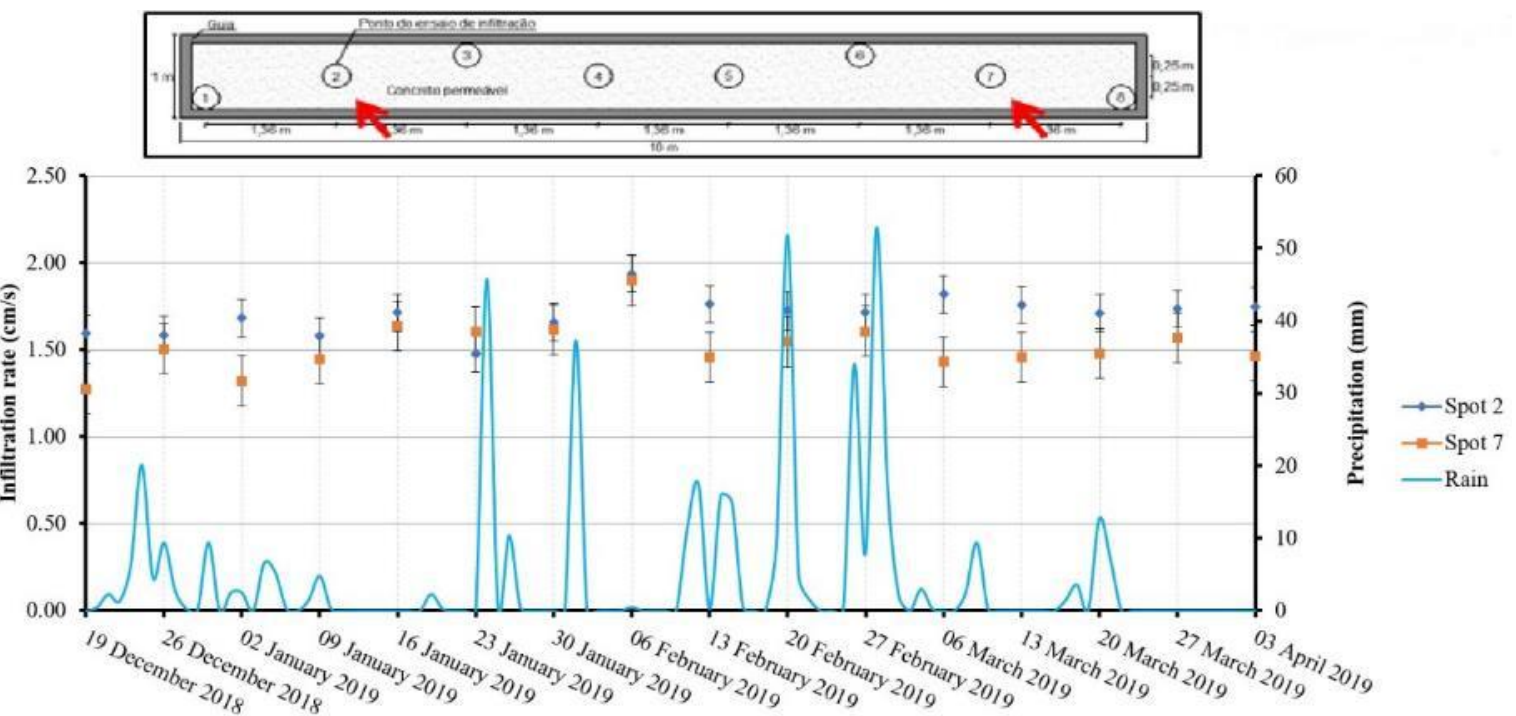

Figure 12: Comparison between the infiltration rates of spots 2 and 7 over time

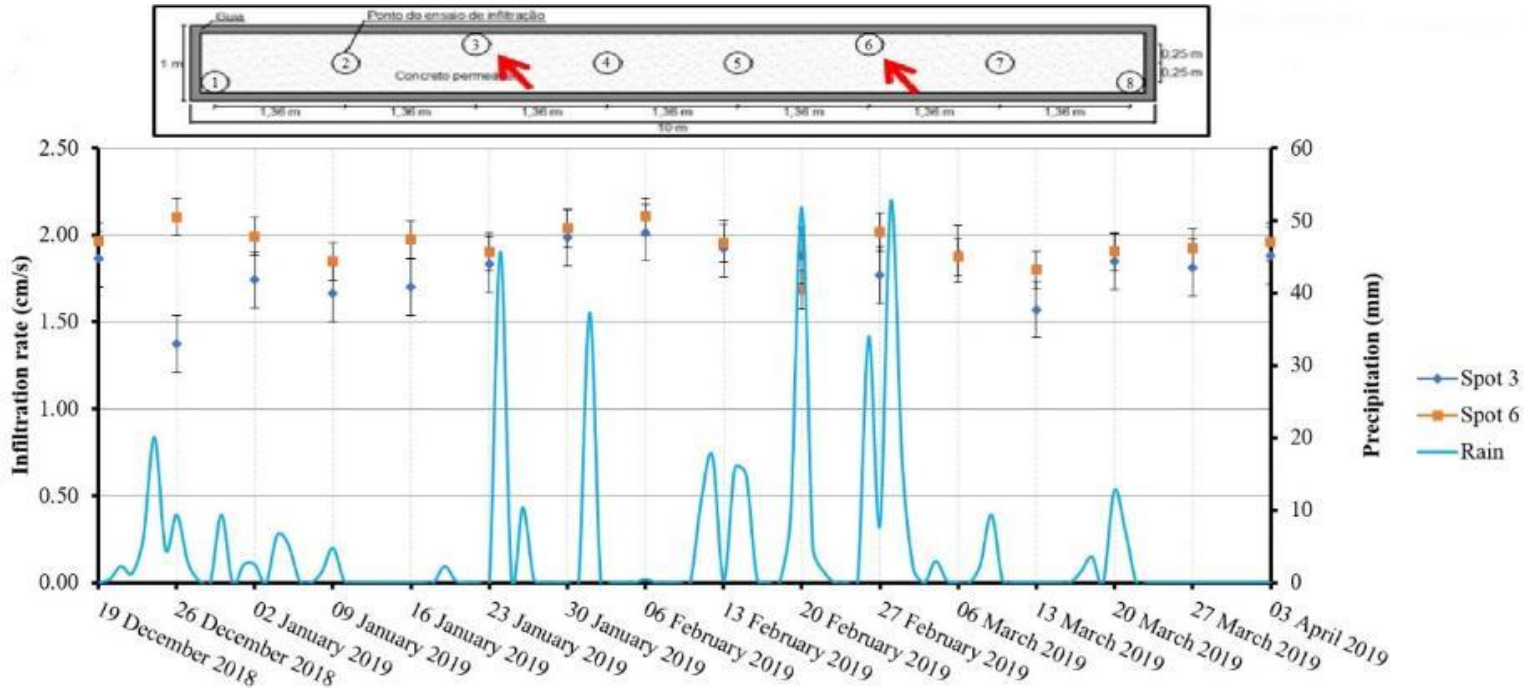

Figure 13: Comparison between the infiltration rates of spots 3 and 6 over time 


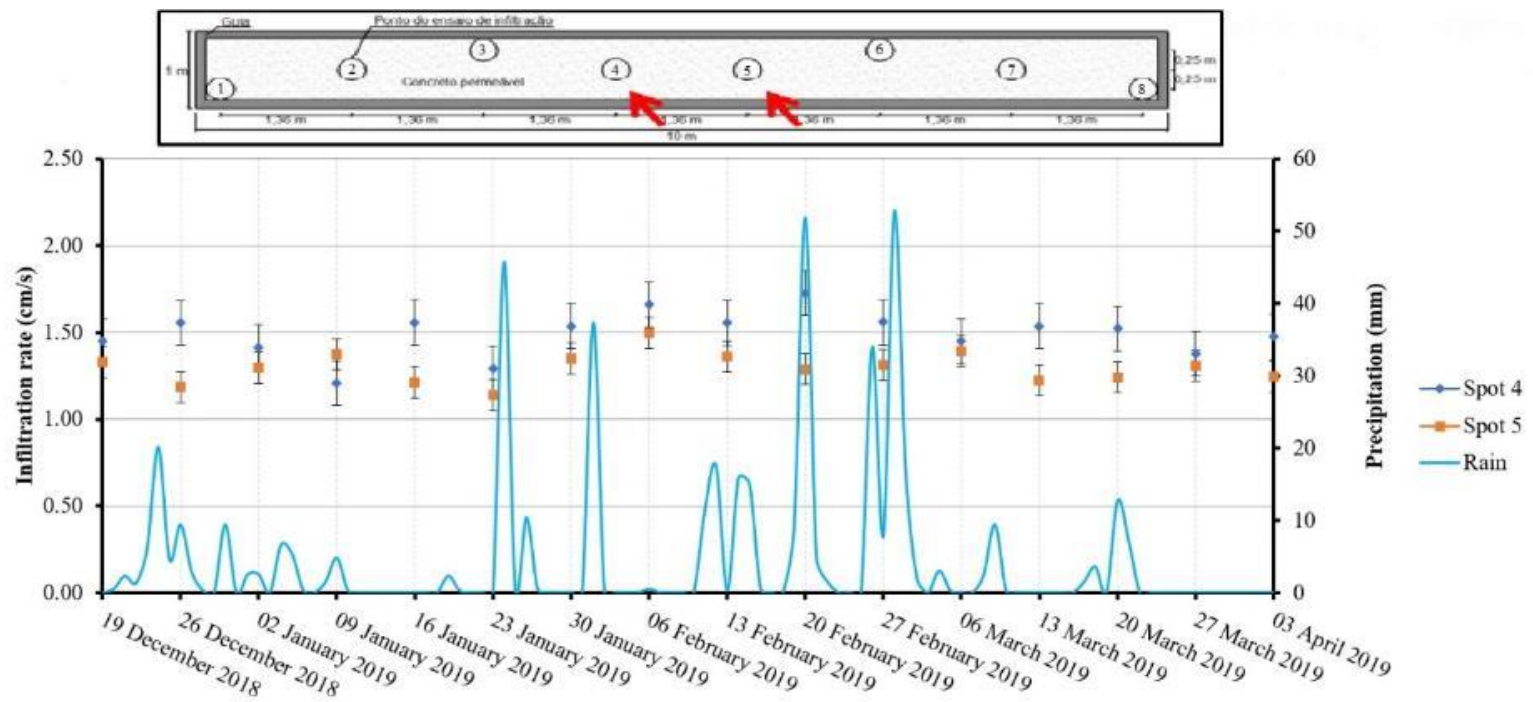

Figure 14: Comparison between the infiltration rates of spots 4 and 5 over time

Spots 1 and 8 were the symmetrical spots with the most distant infiltration rates. The difference between the infiltration rates for the two spots remained approximately constant over time. Table 4 can help to see more clearly the behaviour regarding infiltration rate of spots over time. Monthly cleaned spot 1 showed infiltration rates ranging from $1.09 \mathrm{~cm} / \mathrm{s}$ to a maximum of $1.35 \mathrm{~cm} / \mathrm{s}$, which was the initial infiltration rate, while spot 8 , cleaned weekly, had infiltration rates that ranged from $1.52 \mathrm{~cm} / \mathrm{s}$ to $1.95 \mathrm{~cm} / \mathrm{s}$ over time. Although the infiltration rates were not very close, through the graphical analysis we do not notice a significant difference during the period analysed for the two spots, considering deviations. During the period of the tests, it rained in almost every week. This is common during the summer in the study region. By graphical observation, the rain does not seem to interfere significantly with the infiltration rates. Heavy or less intense rains, near or far from the days of the tests and with more or less rainfall, do not seem to interfere significantly with these measurements.

Table 4: Summary of infiltration rate values for all spots over time

\begin{tabular}{|c|c|c|c|c|c|c|}
\hline SPOT & $\begin{array}{l}\text { MAXIMUM AND } \\
\text { MINIMUM } \\
\text { INFILTRATION } \\
\text { RATE OF ALL } \\
\text { PERIOD (CM/S) } \\
\end{array}$ & $\begin{array}{l}\text { MEAN } \\
\text { OF ALL } \\
\text { PERIOD } \\
(\mathrm{CM} / \mathrm{S})\end{array}$ & $\begin{array}{c}\text { MAXIMUM } \\
- \\
\text { MINIMUM } \\
(\mathrm{CM} / \mathrm{S})\end{array}$ & $\begin{array}{c}\text { MAXIMUM } \\
\text { STANDARD } \\
\text { DEVIATION } \\
\text { (CM/S) }\end{array}$ & $\begin{array}{l}\text { CLEANING } \\
\text { PERIODICITY }\end{array}$ & COMMENTS \\
\hline 1 & $\begin{array}{l}1.35 \\
1.09\end{array}$ & 1.21 & 0.26 & 0.08 & Monthly & \multirow{2}{*}{$\begin{array}{c}\text { Spot } 8 \text { showed a higher variability in the } \\
\text { infiltration rate than spot } 1 \text {, but without } \\
\text { growth infiltration rate over time for both } \\
\text { The mean difference between the two } \\
\text { spots was the biggest }\end{array}$} \\
\hline 8 & $\begin{array}{l}1.95 \\
1.52\end{array}$ & 1.81 & 0.43 & 0.12 & Weekly & \\
\hline 2 & $\begin{array}{l}1.94 \\
1.48\end{array}$ & 1.70 & 0.46 & 0.11 & Monthly & \multirow{2}{*}{$\begin{array}{l}\text { Spot } 7 \text { showed a higher variability in the } \\
\text { infiltration rate than spot } 2 \text {, but without } \\
\text { growth infiltration rate over time for both }\end{array}$} \\
\hline 7 & $\begin{array}{l}1.90 \\
1.28\end{array}$ & 1.52 & 0.62 & 0.14 & Weekly & \\
\hline 3 & $\begin{array}{l}2.01 \\
1.37\end{array}$ & 1.80 & 0.64 & 0.16 & Monthly & $\begin{array}{l}\text { Spot } 6 \text { showed a lower variability in the } \\
\text { infiltration rate than spot } 3 \text {, but without }\end{array}$ \\
\hline
\end{tabular}




\begin{tabular}{c|c|c|c|c|c|c}
\hline 6 & $\begin{array}{l}2.11 \\
1.68\end{array}$ & 1.94 & 0.43 & 0.11 & Weekly & $\begin{array}{c}\text { growth infiltration rate over time for both. } \\
\text { The mean difference between the two } \\
\text { spots was the smallest }\end{array}$ \\
\hline 4 & $\begin{array}{l}1.73 \\
1.21\end{array}$ & 1.49 & 0.52 & 0.13 & Monthly & $\begin{array}{c}\text { Spot 5 showed a lower variability in the } \\
\text { infiltration rate than spot 4, but without } \\
\text { growth infiltration rate over time for both }\end{array}$ \\
\hline
\end{tabular}

For the comparison between spots 2 and 7, although the infiltration rate of spot 2, cleaned monthly, was slightly higher, the difference between the infiltration rates is small. The infiltration rates of spots 2 and 7 ranged from $1.48 \mathrm{~cm} / \mathrm{s}$ to $1.94 \mathrm{~cm} / \mathrm{s}$ and $1.28 \mathrm{~cm} / \mathrm{s}$ to $1.90 \mathrm{~cm} / \mathrm{s}$, respectively, during the observation time. The graphical observation shows that, over time, the values remain close and do not show a reduction in infiltration rate, considering deviations. Again, the rain does not appear to interfere with the infiltration rate.

Comparing spots 3 and 6 , the infiltration rates are very close but on average, spot 6 , which is cleaned weekly, is slightly higher. The infiltration rates ranged from $1.68 \mathrm{~cm} / \mathrm{s}$ to $2.11 \mathrm{~cm} / \mathrm{s}$ for spot 6 , and at spot 3 the rates ranged from $1.37 \mathrm{~cm} / \mathrm{s}$ to $2.01 \mathrm{~cm} / \mathrm{s}$. The infiltration rates over time for these two spots remain relatively unaltered and the rain also does not seem to interfere significantly.

Finally, the behaviour analysis of spots 4 and 5 also showed close infiltration rate values over time. It ranged from $1.21 \mathrm{~cm} / \mathrm{s}$ to $1.73 \mathrm{~cm} / \mathrm{s}$ and $1.14 \mathrm{~cm} / \mathrm{s}$ to $1.50 \mathrm{~cm} / \mathrm{s}$, respectively. As in the other spots, these also presented a constant behaviour without decreases. Rain does not appear to influence either, as noted elsewhere.

As is noticeable graphically, there are no apparently significant reductions of infiltration rates for any of the spots compared. However, there are slight variations at all spots at each weekly test. If one considers the standard deviation of the sample data of each spot during the whole period, the largest deviation is found in spot $3,0.16 \mathrm{~cm} / \mathrm{s}$ with a $9.00 \%$ coefficient of variation. Variabilities in the data can also be found in other works that used the same infiltration rate test method. Li et al. [47] compared the ASTM C1701 infiltration rate measurement method with the National Centre for Asphalt Technology (NCAT) method and observed a maximum deviation of $0.11 \mathrm{~cm} / \mathrm{s}$ for the ASTM method, but its coefficients of variation were higher, around $30 \%$, due to the low permeability rates of the pavements they studied, variations of $0.02 \mathrm{~cm} / \mathrm{s}$ to $0.82 \mathrm{~cm} / \mathrm{s}$ were observed in Asphalt Concrete-Open Graded and Interlocking Concrete Paver-Permeable, respectively. As the infiltration rates of the present study are higher, this deviation can be considered acceptable. Apparently the monthly or weekly cleaning periodicity has similar efficiency, as it did not seem to cause significant differences in the infiltration rate of the pervious pavement during the period considered.

\subsection{Monthly means for the eight spots}

A mean monthly analysis was also performed every four weeks, as seen in Figure 15.

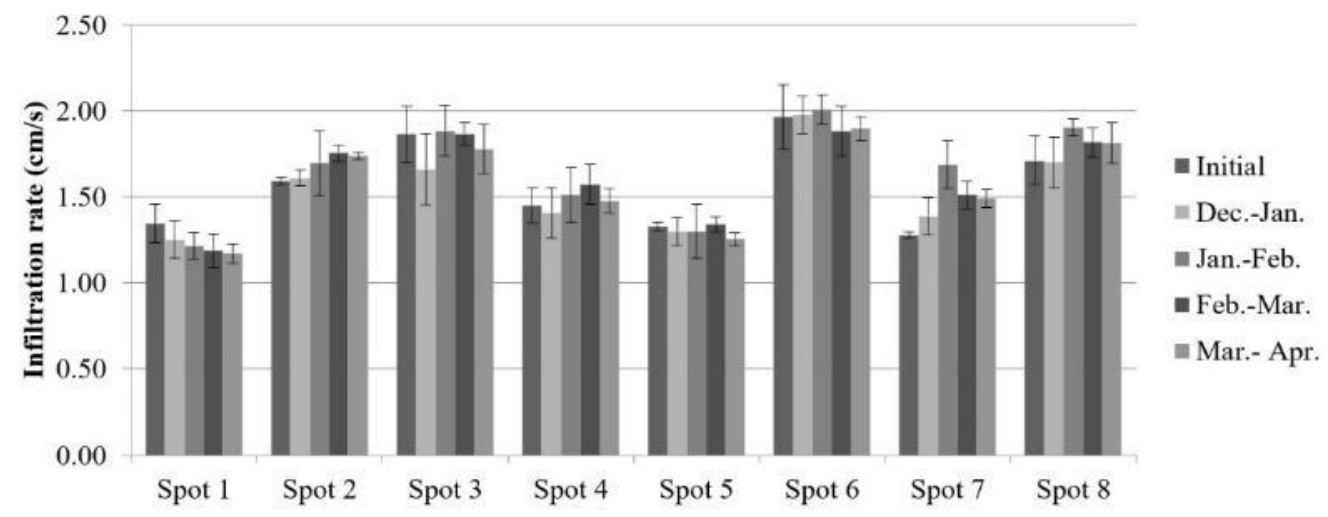

Figure 15: Monthly means of each spot throughout the period of data collection 
The analysis of the monthly means at all spots makes the tendencies of the infiltration rates more evident. Spot 1 is the only one that has an apparent slight reduction of infiltration rate over time, month to month, while spot 2 was the only one that presented a gradual and slight increase in infiltration rate over first three months, stabilizing in the fourth. Both were cleaned monthly. The other spots do not apparently follow a monthly trend, varying over months and, from the standard deviations, spots 7 and 8 presented a slight increase in the infiltration rate in relation to the initial rate. Spots 3, 4, 5 and 6 maintained constant permeabilities when compared to the initial one. Spot 3 presented the highest standard deviation in the monthly means between the same spots in the period from December to January, with $0.21 \mathrm{~cm} / \mathrm{s}$ and a $12.53 \%$ coefficient of variation. This was the period of greatest variability for spot 3 , but it is not too far from the maximum deviation observed for the entire four-month period of data collection, as seen in Section 3.3.

\subsection{Monthly means of the areas with monthly and weekly cleaning}

Figure 16 shows a monthly mean analysis of the four spots on each half of the pavement.

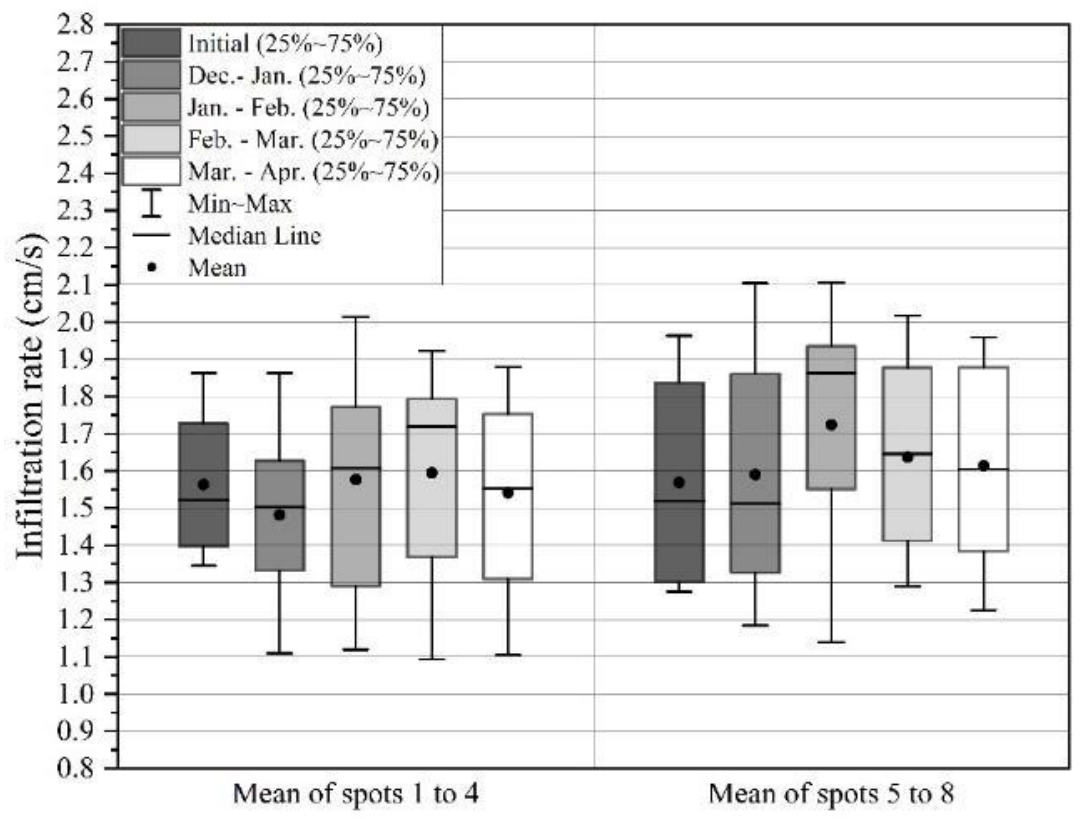

Figure 16: Monthly means of the four spots of each half, cleaned monthly and weekly

The graphical analysis (Figure 16) shows that the half of the pavement cleaned monthly, spots 1-4, and the half cleaned weekly, spots 5-8, do not show significant differences in the infiltration rates, considering the deviation standards. In this case, the deviations were slightly higher because they encompassed the average of the four spots for each half of the pavement and, as the infiltration rate between different spots had greater variation, the maximum deviation seen in this comparison was $0.32 \mathrm{~cm} / \mathrm{s}$ with $20.77 \%$ coefficient of variation. For both halves, the means values over the months also remained practically constant.

\subsection{Statistical analysis}

In order to confirm whether there was a significant difference between the monthly and weekly maintenance and also between the months of data collected, an analysis of variance (ANOVA) was performed, which allows statistically testing if the means of several sampling groups can be considered equal or different from each other.

A two-way ANOVA was performed to investigate all data from the four spots on each half of the pavement for each 28-day period. The two-way ANOVA allowed determining if there was a statistical difference between the monthly and weekly maintenance intervals and if there was a statistical difference between the average data each month. The test was performed with a $0.05(5 \%)$ alpha level and the statistical results are presented in Table 5 . 
Table 5: Statistical results

\begin{tabular}{c|c|c|c}
\hline $\begin{array}{c}\text { SOURCE OF } \\
\text { VARIABILITY }\end{array}$ & F & P-VALUE & F CRITICAL \\
\hline Between spots & 3.7748 & 0.0544 & 3.9201 \\
\hline Between months & 1.0660 & 0.3663 & 2.6802 \\
\hline Interaction & 0.2271 & 0.8774 & 2.6802 \\
\hline
\end{tabular}

Through the statistical test, it was possible to compare the influence of two factors, the monthly and weekly maintenance and the months elapsed for the two data groups. For this analysis, an F value is calculated for the groups tested and an F critical value is observed for the sample groups. Two hypotheses are assumed, the null hypothesis, which recognizes that there is no statistical difference between the means tested, and the alternative hypothesis that considers there is a statistical difference between the means, considering the significance level adopted. In order that the average sample values can be statistically considered equal, and the null hypothesis accepts, $\mathrm{F}$ value $<\mathrm{F}$ critical value and $\mathrm{P}$-value $>0.05$, indicating that there is no significance. An F value > F critical value and P-value < 0.05 means that the means of the sample groups are considered statistically unequal; that is, there is significant variation between the groups of samples tested and the alternative hypothesis is accepted.

Analysing Table 5, the same result is noted for all comparisons, $\mathrm{F}$ value $<\mathrm{F}$ critical value and $\mathrm{P}$ value $>0.05$. That is, statistically, between the parts of the pavement with monthly and weekly maintenance, as well as between the study months, there were no significant differences between the means. The interaction of these two factors also shows that there was no difference between the means of the spots over time and the null hypothesis could be accepted for all conditions.

Therefore, the time did not seem to significantly influence the infiltration rate, at least during the first four months after the pavement placement, showing that using a blower to clean pervious concrete pavements can be considered efficient in pavements with conditions similar to the present research. Finally, both monthly and weekly maintenance had similar behaviour over time, showing that the pavement had no significant loss of permeability during the study time.

When comparing the infiltration rate results of the present study with those of Saaly et al. [22], which showed significant decreases for the same period of observation (four months), without maintenance, in outdoor environmental conditions, it can be seen that the pavement with periodic cleaning presented a much superior performance since it did not present any difference over time.

It is also important to consider that the pavement was built in a site with a low incidence of organic debris and without runoff or drainage from surrounding areas. Other situations with higher debris load of both organic and inorganic origin were not considered.

\section{CONCLUSIONS}

From the analyses, the following conclusions can be drawn:

1. The initial infiltration rate in pervious concrete pavements may vary slightly from spot to spot due to compactness differences along the same pavement. The regions of the pervious concrete that generally exhibit greater compactness are the central ones, while the regions near the curbs appear to be more porous and, consequently, slightly more permeable. Care should be taken in these edge regions during placement in order to ensure more efficient compaction. Perhaps using a smaller roller and passing it more often close to the curbs can help better disperse the concrete and improve compaction in these regions.

2. The analysis between symmetrical spots with monthly and weekly maintenance shows that, although in some cases the spots have different infiltration rates between them, there were no significant differences in the same spots over time, and rainfall events did not seem to influence the infiltration rate tests when they occurred a short time before or a long time before the infiltration rate tests.

3. Although the initial infiltration rates were somewhat different between the different spots, the average values of the four symmetrical spots for monthly (spots 1-4) and weekly (spots 5-8) 
maintenance were practically equal.

4. There was no statistically significant difference between the infiltration rate means over the months between the two parts of the pavement with different cleaning periods, confirming that both weekly and monthly cleaning using a blower has the same apparent efficiency. This did not occur in the literature when periodic maintenance was not performed. Monthly maintenance is the most suitable, considering the conditions of this study, since less time and fuel are spent for cleaning, collaborating as an environmental-friendly alternative.

5. The blower equipment used to clean the pavement was shown to be efficient, at least in the first months of pavement installation, contributing to prevent clogging and, thus, extending the service life of the pavement in terms of infiltration rate.

6.

\section{ACKNOWLEDGEMENTS}

The authors would like to acknowledge the sponsor companies Votorantim Cimentos, GCP Applied Technologies, Brambilla and Mineração Grandes Lagos for support in services and materials. This study was financed in part by the Coordenação de Aperfeiçoamento de Pessoal de Nível Superior - Brasil (CAPES) Finance Code 001.

\section{DISCLOSURE STATEMENT}

No potential conflict of interest was reported by the authors.

\section{BIBLIOGRAPHY}

[1] ESTEVES, R.L., "Quantificação das superfícies impermeáveis em áreas urbanas por meio de sensoriamento remoto," Universidade de Brasília, 2006.

[2] FERGUSON, B.K., Porous Pavements: integrative studies in water management and land development. London: Taylor \& Francis, 2005.

[3] TENNIS, P.D., LEMING, M.L., AKERS, D.J., Pervious Concrete Pavements. Portland Cement Association, 2004.

[4] LORENZI, A., HASELBACH, L., SILVA FILHO, L.C.P., et al. "Thermal profiles in pervious concrete during summer rain simulations," Matéria (Rio de Janeiro), vol. 23, no. 3, Oct. 2018.

[5] MCCAIN, G.N., DEWOOLKAR, M.M., "Strength and Permeability Characteristics of Porous Concrete Pavements," Journal of the Transportation Research Board, pp. 1-13, 2009.

[6] KIA, A., WONG, H.S., CHEESEMAN, C.R., "Clogging in permeable concrete: A review," Journal of Environmental Management, vol. 193, pp. 221-233, 2017.

[7] BONICELLI, A., GIUSTOZZI, F., CRISPINO, M., "Experimental study on the effects of fine sand addition on differentially compacted pervious concrete," Construction and Building Materials, vol. 91, pp. 102-110, Aug. 2015.

[8] ALSHAREEDAH, O., NASSIRI, S., "Pervious concrete mixture optimization, physical, and mechanical properties and pavement design: A review," Journal of Cleaner Production, vol. 288, p. 125095, Mar. 2021.

[9] KAYHANIAN, M., ANDERSON, D., HARVEY, J.T., et al. "Permeability measurement and scan imaging to assess clogging of pervious concrete pavements in parking lots," Journal of Environmental Management, vol. 95, no. 1, pp. 114-123, 2012.

[10] KIA, A., WONG, H. S., CHEESEMAN, C.R., "Defining clogging potential for permeable concrete," Journal of Environmental Management, vol. 220, no. May, pp. 44-53, 2018.

[11] LIU, R., LIU, H., SHA, F., et al. "Investigation of the Porosity Distribution, Permeability, and Mechanical Performance of Pervious Concretes," Processes, vol. 6, no. 7, p. 78, Jun. 2018.

[12] MAGUESVARI, M.U., NARASIMHA, V.L., "Studies on Characterization of Pervious Concrete for Pavement Applications," Procedia - Social and Behavioral Sciences, vol. 104, pp. 198-207, Dec. 2013.

[13] WERNER, B., HASELBACH, L., "Temperature and Testing Impacts on Surface Infiltration Rates of Pervious Concrete," Journal of Cold Regions Engineering, vol. 31, no. 2, p. 04017002, Jun. 2017. 
[14] SANDOVAL, G.F.B., GALOBARDES REYES, I., SCHWANTES-CEZARIO, N., et al. “Correlation between Permeability and Porosity for Pervious Concrete (PC)," DYNA, vol. 86, no. 209, pp. 151-159, Apr. 2019.

[15] SANDOVAL, G.F.B., GALOBARDES, I., TEIXEIRA, R.S., et al. "Comparison between the falling head and the constant head permeability tests to assess the permeability coefficient of sustainable Pervious Concretes," Case Studies in Construction Materials, vol. 7, pp. 317-328, Dec. 2017.

[16] DELATTE, N., MILLER, D., MRKAJIC, A., "Portland cement pervious concrete pavement: Field performance investigation on parking lot and roadway pavements," RMC Research \& Education Foundation, p. 76, 2007, [Online]. Available: http://trid.trb.org/view.aspx?id=1152804.

[17] COUGHLIN, J.P., CAMPBELL, C.D., MAYS, D.C., "Infiltration and Clogging by Sand and Clay in a Pervious Concrete Pavement System,” Journal of Hydrologic Engineering, vol. 17, no. 1, pp. 68-73, Jan. 2012.

[18] SANDOVAL, G.F.B., GALOBARDES, I., CAMPOS, A., et al. "Assessing the phenomenon of clogging of pervious concrete (Pc): Experimental test and model proposition," Journal of Building Engineering, vol. 29, no. January, 2020.

[19] SANDOVAL, G.F.B., DE MOURA, A.C., JUSSIANI, E.I., et al. "Proposal of maintenance methodology for pervious concrete (PC) after the phenomenon of clogging," Construction and Building Materials, vol. 248, p. 118672, Jul. 2020.

[20] CUI, X., ZHANG, J., HUANG, D., et al. "Experimental simulation of rapid clogging process of pervious concrete pavement caused by storm water runoff," International Journal of Pavement Engineering, vol. 20, no. 1, pp. 24-32, Jan. 2019.

[21] DEO, O., SUMANASOORIYA, M., NEITHALATH, N., "Permeability Reduction in Pervious Concretes due to Clogging: Experiments and Modeling," Journal of Materials in Civil Engineering, vol. 22, no. 7, pp. 741-751, Jul. 2010.

[22] SAALY, M., HEDAYAT, M.M., GOLROO, A., "Performance of pervious concrete pavement under various raining conditions," Road Materials and Pavement Design, vol. 20, no. 7, pp. 1653-1663, Oct. 2019.

[23] WINSTON, R.J., AL-RUBAEI, A.M., BLECKEN, G.T., et al. "Maintenance measures for preservation and recovery of permeable pavement surface infiltration rate - The effects of street sweeping, vacuum cleaning, high pressure washing, and milling," Journal of Environmental Management, vol. 169, pp. 132-144, Mar. 2016.

[24] HENDERSON, V., TIGHE, S., "Evaluation of pervious concrete pavement performance in cold weather climates,” International Journal of Pavement Engineering, vol. 13, no. 3, pp. 197-208, Jun. 2012.

[25] VANCURA, M.E., MACDONALD, K., KHAZANOVICH, L., "Location and Depth of Pervious Concrete Clogging Material before and after Void Maintenance with Common Municipal Utility Vehicles," Journal of Transportation Engineering, vol. 138, no. 3, pp. 332-338, Mar. 2012.

[26] HEIN, M.F., DOUGHERTY, M., HOBBS, T., "Cleaning Methods for Pervious Concrete Pavements," International Journal of Construction Education and Research, vol. 9, no. 2, pp. 102-116, Apr. 2013.

[27] DEPARTAMENTO DE ÁGUAS E ENERGIA ELÉTRICA, "DAEE: Precipitações intensas no estado de São Paulo," 2018.

http://www.daee.sp.gov.br/index.php?option=com_content \&view=article \&id=743\%3Apluviografia\&catid=4 3\%3Ahidrometeorologia\&Itemid=30 (accessed Sep. 30, 2018).

[28] WEATHER SPARK, “Condições meteorológicas médias de Ilha Solteira,” 2019.

https://pt.weatherspark.com/ (accessed Mar. 26, 2019).

[29] RIBEIRO, R.A.V., “Avaliação do desempenho hidráulico de barreiras de proteção ambiental produzidas com solo laterítico arenoso compactado, estabilizado quimicamente," Universidade Estadual Paulista.

Campus de Ilha Solteira, 2002.

[30] LOLLO, J.A., "Soil Permeability of Ilha Solteira," 2018.

[31] ASSOCIAÇÃO BRASILEIRA DE NORMAS TÉCNICAS, "NBR 7211: Agregados para concreto. Especificação,”p. 9, 2009.

[32] ASSOCIAÇÃO BRASILEIRA DE NORMAS TÉCNICAS, "NBR 16697: Cimento Portland. Requisitos," p. 12, 2018. 
[33] "CIMENTOS VOTORANTIM: OBRAS ESTRUTURAIS.”

https://www.votorantimcimentos.com.br/produtos/cimentos-itau/obras-estruturais-4/ (accessed Mar. 27, 2021).

[34] MIKAMI, R.J., KRUGER, P., PEREIRA, E., et al. "Influência do teor de cerâmica vermelha do agregado reciclado nas propriedades do concreto permeável," Matéria (Rio de Janeiro), vol. 23, no. 3, Oct. 2018.

[35] BATEZINI, R., "Estudo preliminar de concretos permeáveis como revestimento de pavimentos para áreas de veículos leves,” Universidade de São Paulo, 2013.

[36] ASTM International, “C39/C39M - 18: Standard test method for compressive strength of cylindrical concrete specimens,” Annual Book of ASTM Standards, pp. 1-7, 2018.

[37] ASTM International, “C496/C496M - 17: Standard Test Method for Splitting Tensile Strength of cylindrical concrete specimens,” Annual Book of ASTM Standards, pp. 1-5, 2017.

[38] ASTM International, "C78/C78M-18: Standard Test Method for Flexural Strength of Concrete (Using Simple Beam with Third-Point Loading),” Annual Book of ASTM Standards, pp. 1-7, 2018.

[39] ASTM International, "C1688/C1688M - 14A: Standard test method for density and void content of freshly mixed pervious concrete,” Annual Book of ASTM Standards, pp. 1-3, 2014, [Online]. Available: https://compass.astm.org/download/C1688C1688M.18914.pdf.

[40] ASTM International, “C642 - 13: Standard Test Method for Density, Absorption, and Voids in Hardened Concrete ASTM,” Annual Book of ASTM Standards, pp. 1-3, 2013.

[41] INTERNATIONAL ORGANIZATION FOR STANDARDIZATION, "ISO 17785-1: Testing methods for pervious concrete - Part 1: Infiltration rate,” Vernier, 2016.

[42] AMERICAN CONCRETE INSTITUTE, “ACI 522R: Report on pervious concrete,” Farmington Hills, 2010.

[43] ASTM International, “C1701/C1701M - 17a: Standard Test Method for Infiltration Rate of In Place Pervious Concrete,” Annual Book of ASTM Standards, pp. 9-11, 2017, [Online]. Available:

https://www.astm.org/Standards/C1701.htm.

[44] DRAKE, J., BRADFORD, A., “Assessing the potential for restoration of surface permeability for permeable pavements through maintenance,” Water Science and Technology, vol. 68, no. 9, pp. 1950-1958, Nov. 2013.

[45] ASSOCIAÇÃO BRASILEIRA DE NORMAS TÉCNICAS, "NBR 16416: Pavimentos Permeáveis de concreto - Requisitos e procedimentos," p. 25, 2015.

[46] UNIVERSIDADE ESTADUAL PAULISTA - UNESP, “Canal Clima da UNESP,” 2019. http://clima.feis.unesp.br (accessed Apr. 04, 2019).

[47] LI, H., KAYHANIAN, M., HARVEY, J. T., "Comparative field permeability measurement of permeable pavements using ASTM C1701 and NCAT permeameter methods," Journal of Environmental Management, vol. 118, pp. 144-152, 2013.

\section{ORCID}

Rodrigo Garozi da Silva

Maria da Consolação Fonseca de Albuquerque

Marcelo Bortoletto

Felipe de Almeida Spósito

Aparecido Carlos Gonçalves

Marco Antonio de Morais Alcântara https://orcid.org/0000-0002-6190-1510

https://orcid.org/0000-0002-9255-868X

https://orcid.org/0000-0002-0435-8953

https://orcid.org/0000-0002-7446-3038

https://orcid.org/0000-0001-5376-3392

https://orcid.org/0000-0002-3494-8911 